\title{
Drėgnojo vandens garo poveikis grybinių ligų ir pupinių amarų plitimui cukrinių runkelių pasèlyje
}

\section{Zita Brazienè \\ Lietuvos agrarinių ir mišku mokslų centro \\ Rumoku bandymu stotis, \\ Klausučiai, LT-70462 Vilkaviškio $r$. \\ El.paštas:rumokai@post.omnitel.net}

\section{Regina Vasinauskienè}

Šilumos ir biotechnologijų inžinerijos katedra, Aleksandro Stulginskio universitetas, Universiteto g. 15, Akademija, LT-53361 Kauno $r$.

El.paštas: regina.vasinauskiene@asu.lt
2008-2009 m. Aleksandro Stulginskio universiteto (ASU), tuo metu - Lietuvos žemès ūkio universiteto, Bandymų stotyje atliekant piktžolių naikinimo sukuriant aukštatemperatūrę aplinką (naudojant drègnajji vandens garą) tyrimus, buvo pastebètas ir ivvertintas garo poveikis lapu grybinių ligų ir pupinio amaro Aphis fabae Scop. plitimui cukrinių runkelių pasèlyje. Naudojant drègnajji vandens garą 3 kartus runkelių vegetacijos laikotarpiu, grybinių ligų intensyvumas rugpjūčio pradžioje (I apskaitos metu) buvo 48,1-55,6 \% mažesnis negu kontroliniuose laukeliuose. Rugsejo pabaigoje (II apskaitos metu) grybinių ligų intensyvumas drègnuoju vandens garu apipurkštuose laukeliuose buvo sumažęjęs 54,2-58,3 \%. Pirmos apskaitos metu labiausiai $(67,8-79,0 \%)$ buvo sumažèjęs rudmargès intensyvumas, antros apskaitos metu - miltligès $(79,4-88,2 \%)$ intensyvumas.

Drègnojo vandens garo poveikis amarams nustatytas ir ịvertintas tik $2009 \mathrm{~m}$. laukeliuose, kuriuose liepos viduryje buvo panaudotas vandens garas, amaru apniktų augalų kiekis sumažejo $61,5 \%$, o amarų skaičius ant augalo - 51,8 \%,palyginti su kontroliniais laukeliais.

Raktažodžiai: Aphis fabae, Ramularia beticola, Cercospora beticola, Erysiphe betae

\section{IVADAS}

Šiuo metu pasaulyje sparčiai plintant ekologinei žemdirbystei, vis didesnę reikšmę igyja ekologiškai švarūs žaldarių naikinimo būdai. Ivairių šalių ekologiniuose ūkiuose plinta fizikiniai piktžolių naikinimo būdai, naudojamos įvairios aukštatemperatūrès aplinkos: degimo dujos (Ascard, 1995; Tei, Stagnari, 2003), karštos putos (Collins, Bertram, 2003), karštas vanduo (Hanson, Ascard, 2002; Kurfes, 2000), drègnasis vandens garas (Sirvydas ir kt., 2006; Virbickaite ir kt., 2006). Drégnojo vandens garo panaudojimas pagristas augalo energine apykaita. Piktžolių terminio naikinimo metu, naudojant drégnojo vandens garo aplinką, augalas patenka ị ypatingas termoenerginès apykaitos sąlygas. Drègnojo vandens garo aplinka visiškai prisotinta drègme, kurios temperatūra apie $100{ }^{\circ} \mathrm{C}$. Garas kondensuojasi augalų ir dirvos paviršiuje. Dèl labai didelio kondensacijos proceso šilumos atidavimo koeficiento $(\alpha=50000-100000 \mathrm{~W} /$ $\left.\left(\mathrm{m}^{2} \cdot \mathrm{K}\right)\right)$ šalti paviršiai akimirksniu pasiekia temperatūrą, artimą garo temperatūrai (Sirvydas ir kt., 2006). Praejus garo srautui temperatūra aplinkoje staigiai mažèja, tačiau palieka aukštesnè už pradinę aplinkos temperatūrą (Sirvy- das ir kt. 2008). Šitaip sutrikdoma augalo transpiracija ir jo audiniuose temperatūra pakyla per $58{ }^{\circ} \mathrm{C}$, taip sutrikdomi augalo gyvybiniai procesai, sukeliantys augalų ir piktžolių žūtị (Kerpauskas ir kt., 2006).

Apsaugojus pasèlius nuo piktžolių, svarbu atkreipti dèmesị ị kitus daug nuostolių pridarančius žaldarius. Tai grybinès augalų ligos ir kenkèjai. Dèl grybinių ligų cukrinių runkelių derliaus nuostoliai sudaro vidutiniškai $30 \%$, o palankiomis žalingiesiems organizmams plisti sąlygomis gali siekti $50 \%$ ir daugiau (Wolf, Verreet, 2002). Lietuvoje šiuo metu didžiausią žalą cukrinių runkelių pasèliams padaro rudmargè (sukèlèjas - Cercospora beticola Sacc.) ir baltuliai (sukèlèjas - Ramularia beticola Fautrey \& F. Lamb.) (Gaurilčikienè ir kt., 2006). Ligu pažeistuose lapuose silpnai vyksta fotosintezès ir asimiliacijos procesai, sumažeja azoto, fosforo, kalio ir tirpiụjų angliavandenių, padidèja šakniavaisių alfa aminoazoto kiekis ir sumažèja cukringumas (Boten, Šikalčik, 2001). Miltligè (sukèlèjas - Erysiphe betae Vanha Weltzien) Lietuvoje išplinta ne kiekvienais metais. Tai priklauso nuo meteorologinių sąlygų. Ši liga išplinta, kai nakties ir dienos temperatūrų skirtumas būna didelis ir ant augalų susidaro gausi rasa (Hudec, Rohačik, 2002). 
Esant palankioms sąlygoms, miltligè plinta labai sparčiai, todèl fungicidus reikia naudoti pastebejjus pirmuosius ligos požymius (Dabkevičius, Brazauskienè, 2007).

Dẻl kenkẻjų pažeidimų cukrinių runkelių augintojai gali prarasti iki $24 \%$ šakniavaisių derliaus, taip pat sumažěja lauko daigumas. Runkelių pasèliams kenkia runkelinè spragè (Chaetocnema concinna March.), runkelinè musè (Pegomya hyoscyami Panz.), pupinis amaras (Aphis fabae Scop.) (Vizgirda, 1997). Amarų apnikti augalai išaugina iki $30 \%$ mažesnį šakniavaisių derlių. Amarai žalingi ir tuo, kad platina runkelių virusines ligas (Limburg et al., 1997). Nustatyta, kad apsaugos priemonėmis sumažinus amarų skaičių, virusinės geltos išplitimas sumažèja 69-81 \% (Meredith, Morris, 2003). Runkelinių amarų žalingumo riba laikoma 10 \% šių kenkëjų apniktų augalų.

Naudojant drégnojo vandens garo aplinką piktžolių kontrolei buvo pastebèta, kad tuose pasèlių ploteliuose kultūriniai augalai yra mažiau pažeisti žaldarių.

Darbo tikslas - nustatyti drégnojo vandens garo poveiki grybinių ligų ir pupinių amarų paplitimui cukrinių runkelių pasèlyje.

\section{METODAI IR SĄLYGOS}

Lauko bandymai cukrinių runkelių pasèlyje buvo atliekami ASU (tuo metu - LŽŨU) Bandymų stotyje 2008-2009 m.

Tyrimo vietos ir dirvožemio charakteristika. ASU Bandymų stotis yra Kauno rajone, pietvakarinėje Kauno miesto pusèje, kairiajame Nemuno krante. Bandymų stoties dirvožemiai priklauso Baltijos aukštumų zonai, Nemuno vidurupio plynaukštes smèlingujjų ir dulkiškujų priemoliu paprastụjų, karbonatingųjų glèjiškụjų bei stagniškųjų išplautžemių rajonui. Tyrimai atlikti priemolio sekliai glejjiškame išplautžemyje - IDg4-K2 (Calcari-Hypogleyic Luvisol). Dirvos ariamasis sluoksnis $(0-20 \mathrm{~cm})$ buvo neutralios ir silpnai šarmiškos reakcijos $\left(\mathrm{pH}_{\mathrm{KCl}} 7,02-7,13\right)$, vidutinio humusingumo (2,23-2,50\%), vidutinio, didelio ir labai didelio fosforingumo $\left(123,96-294,95 \mathrm{mg} \mathrm{kg}^{-1}\right)$, didelio ir labai didelio kalingumo (144,28-197,31 $\left.\mathrm{mg} \mathrm{kg}^{-1}\right)$.

Cukriniai runkeliai 'Ernestina' pasèti balandžio III dešimtadienị. Bandymų laukas $18 \times 40 \mathrm{~m}$; laukelių dydis $3 \times 9 \mathrm{~m}$. Cukriniai runkeliai pasèti $50 \mathrm{~cm}$ tarpueiliais, atstumas tarp séklu $18 \mathrm{~cm}$. Fungicidai ir insekticidai nenaudoti. Herbicidai naudoti tik pirmame variante. Drégnasis vandens garas naudojamas $100{ }^{\circ} \mathrm{C}$, aplinką jis veikia 1-2 sekundes.

1 variantas. Pirmas purškimas Betanal Expert 1,25 $1 \mathrm{ha}^{-1}$, pradëjus dygti piktžolèms, antras purškimas Betanal Expert 1,25 $1 \mathrm{ha}^{-1}$, praejus 5 dienoms po pirmo purškimo.

2 variantas. Pirmą kartą drègnasis vandens garas panaudotas 5-6 d. po sèjos. Visas pasèlis buvo veikiamas drègnuoju vandens garu, kadangi cukriniai runkeliai dar nebuvo sudygę. Antrą kartą drègnasis vandens garas buvo panaudotas, praèjus 5 dienoms po runkelių sudygimo. Cukriniai runkeliai nuo drégnojo vandens garo poveikio buvo apsaugoti gaubtais.

3 variantas. Drėgnasis vandens garas buvo naudotas 3 kartus per cukriniu runkelių vegetacijos periodą. Pirmą kartą - ištisinis plikinimas prieš runkelių sudygimą. Antrą kartą drègnasis vandens garas panaudotas, praëjus 5 dienoms po runkelių sudygimo. Tuomet cukriniai runkeliai nuo drègnojo vandens garo poveikio buvo apsaugoti gaubtais. Trečią kartą runkeliai purkšti liepos I dešimtadienį. Ši kartą gaubtai nebuvo naudojami, kadangi runkeliai 33-39 BBCH augimo tarpsnyje atsparūs trumpalaikiam drègnojo vandens garo poveikiui.

Lapų ligos apskaita atlikta 2 kartus: rugpjūčio I dešimtadienị ir rugsëjo III dešimtadieni (prieš nuimant derlių). Apskaitų metu buvo vizualiai ịvertintas ligų pažeistas lapų plotas.

Lapų ligų intensyvumas (\%) skaičiuotas pagal formulę (Žemès ükio augalu...., 2002):

$$
R=\frac{\Sigma(n b)}{N}
$$

čia $\Sigma(n b)$ - vienodai (\%) pažeistų lapų skaičiaus ir pažeidimo reikšmès sandaugų suma; $N$ - visų patikrintų lapų skaičius.

Amarų apskaitos atliktos liepos pradžioje prieš trečią purškimą drégnuoju vandens garu ir praèjus savaitei po purškimo. Amarų apnikti augalai (\%) buvo nustatyti pagal formulę:

$$
P=\frac{n \times 100}{N}
$$

čia $n$ - kenkèjų apniktų augalų skaičius mėginiuose; $N$ - patikrintų augalu skaičius.

Vidutinis kenkejų skaičius, tenkantis apniktam augalui, nustatytas pagal formulę:

$$
K=\frac{m}{M}
$$

čia $m$ - kenkèjų skaičius apniktuose augaluose; $M$ - apniktų augalų skaičius.

Bandymų duomenys statistiškai apdoroti programa ANOVA (Tarakanovas, Raudonius, 2003).

Meteorologinès sąlygos. $2008 \mathrm{~m}$. pavasaris buvo ankstyvas ir šiltas. Antrą balandžio dešimtadienị iškrito $24 \mathrm{~mm}$ kritulių, tačiau dèl šilto oro dirvos sparčiai džiūvo (1 lentelè).

Gegužès pradžia buvo šilta, krituliai sudare tik 38,1 \% daugiamečio vidurkio, todèl dygstantiems runkeliams trūko drègmès. Birželis buvo šiltas ir lietingas, palankus augalų vystymuisi ir augimui. Dèl sausos liepos sutriko cukrinių runkelių augimas. Šiltas ir lietingas rugpjūtis sudarè palankias sąlygas plisti grybinèms lapų ligoms. Rugsèjo pradžia buvo sausa ir šilta. Antrą dešimtadienị orai atvèso, vidutinè 
1 lentelè. Meteorologinès sąlygos cukrinių runkelių vegetacijos laikotarpiu

Table 1. Air temperature and precipitation during sugar-beet growth period

\begin{tabular}{|c|c|c|c|c|c|c|c|}
\hline \multirow[b]{2}{*}{ Mènuo/Month } & \multirow{2}{*}{$\begin{array}{c}\text { Dekada / } \\
\text { Decade }\end{array}$} & \multicolumn{3}{|c|}{ Vid. oro temperatūra ${ }^{\circ} \mathrm{C} /$ Air temperature, ${ }^{\circ} \mathrm{C}$} & \multicolumn{3}{|c|}{ Kritulių kiekis mm / Precipitation mm } \\
\hline & & 2008 & 2009 & $\begin{array}{l}\text { Vid. daugiametis } \\
\text { Average perennial }\end{array}$ & 2008 & 2009 & $\begin{array}{l}\text { Vid. daugiametis } \\
\text { Average perennial }\end{array}$ \\
\hline \multirow{4}{*}{$\begin{array}{c}\text { Balandis } \\
\text { April }\end{array}$} & 1 & 7,6 & 8,1 & 4,4 & 7,3 & 8,6 & 14,0 \\
\hline & II & 7,9 & 7,5 & 5,3 & 24,5 & 0 & 14,0 \\
\hline & III & 11,0 & 11,2 & 7,8 & 0,3 & 0 & 14,0 \\
\hline & & 8,8 & 8,9 & 5,8 & 32,1 & 8,6 & 42,0 \\
\hline \multirow{4}{*}{$\begin{array}{c}\text { Gegužè } \\
\text { May }\end{array}$} & 1 & 12,0 & 11,4 & 10,9 & 6,1 & 12,6 & 16,0 \\
\hline & II & 11,8 & 11,7 & 12,6 & 9,0 & 8,7 & 19,0 \\
\hline & III & 13,0 & 14,8 & 13,5 & 20,4 & 20,7 & 20,0 \\
\hline & & 12,3 & 12,7 & 12,4 & 35,5 & 42,0 & 55,0 \\
\hline \multirow{4}{*}{$\begin{array}{l}\text { Birželis } \\
\text { June }\end{array}$} & 1 & 17,6 & 12,6 & 15,3 & 0,0 & 49,6 & 16,0 \\
\hline & II & 15,1 & 13,5 & 15,7 & 38,3 & 40,6 & 27,0 \\
\hline & III & 15,4 & 18,4 & 16,5 & 44,9 & 17,2 & 26,0 \\
\hline & & 16,0 & 14,8 & 15,8 & 83,2 & 107,4 & 69,0 \\
\hline \multirow{4}{*}{$\begin{array}{l}\text { Liepa } \\
\text { July }\end{array}$} & 1 & 16,9 & 18,0 & 16,5 & 21,6 & 22,0 & 23,0 \\
\hline & II & 17,9 & 19,3 & 16,9 & 16,8 & 37,7 & 28,0 \\
\hline & III & 19,3 & 18,0 & 17,4 & 4,6 & 23,6 & 29,0 \\
\hline & & 18,1 & 18,4 & 16,9 & 43,0 & 83,3 & 80,0 \\
\hline \multirow{4}{*}{$\begin{array}{l}\text { Rugpjūtis } \\
\text { August }\end{array}$} & 1 & 18,3 & 18,4 & 17,6 & 35,2 & 0,0 & 28,0 \\
\hline & II & 19,7 & 16,6 & 16,4 & 36,3 & 26,2 & 26,0 \\
\hline & III & 16,0 & 15,7 & 15,2 & 27,8 & 61,3 & 24,0 \\
\hline & & 17,9 & 16,9 & 16,4 & 99,3 & 87,5 & 78,0 \\
\hline \multirow{4}{*}{$\begin{array}{l}\text { Rugsèjis } \\
\text { September }\end{array}$} & 1 & 17,3 & 15,7 & 13,5 & 3,0 & 12,5 & 19,0 \\
\hline & II & 8,8 & 13,5 & 11,7 & 8,5 & 9,7 & 20,0 \\
\hline & III & 10,6 & 12,4 & 10,2 & 15,5 & 6,1 & 17,0 \\
\hline & & 12,2 & 13,8 & 11,5 & 27,0 & 28,3 & 56,0 \\
\hline
\end{tabular}

paros temperatūra buvo $2,9^{\circ} \mathrm{C}$ mažesnè už vidutinę daugiametę. Drègmès trūko visą mènesi - kritulių buvo tik 48,2 \% vidutinio daugiamečio vidurkio.

2009 m. pavasaris taip pat buvo ankstyvas ir šiltas. Tačiau po sėjos runkelių dygimui labai trūko drègmès. Balandi krituliai sudare tik 20,5\% vidutinio daugiamečio vidurkio. Gegužę kritulių pakako. Sudygo anksčiau nesudygę runkeliai, todèl pasèlis buvo labai nevienodas. Birželio ir liepos orai buvo palankūs runkelių vegetacijai ir šakniavaisių masès augimui bei nepalankūs grybinėms ligoms vystytis.

Rugpjūčio antroji pusẻ buvo šilta ir lietinga. Kritulių iškrito daugiau už daugiametị vidurkị. Rugsèjo vidutinè paros oro temperatūra buvo $2,3{ }^{\circ} \mathrm{C}$ didesnè, palyginus su vidutine daugiamete. Kritulių iškrito $27,7 \mathrm{~mm}$ mažiau, palyginus su daugiamete norma.

\section{REZULTATAI IR JŲ APTARIMAS}

Naikinant cukrinių runkelių piktžoles drėgnuoju vandens garu, buvo pastebèta, kad augalų ligotumas sumažèjo. Norẻdami tiksliai ịvertinti šio garo poveikį, atlikome grybinių ligų apskaitas rugpjūčio pradžioje ir rugsẻjo pabaigoje prieš nuimant derlių. Tyrimų metais bandymų laukeliuose buvo paplitusios rudmargè, baltuliai ir miltligè. Fomozès ir rūdžių aptikta tik 2009 m. ir tik keliose vietose. Todèl šių ligų apskaitos duomenų straipsnyje nepateikiame. Tyrimų metais pirmos apskaitos metu rugpjūčio pradžioje rudmargès intensyvumas cukrinių runkelių pasèlyje buvo panašus, nepurkštuose drègnuoju vandens garu laukeliuose jis kito nuo 1,18 iki 1,57 \% (2 lentelè).

Pasèlį nupurškus drègnuoju vandens garu rudmargès intensyvumas sumažèjo: 31,2-62,7 \% (nupurškus 2 kartus vegetacijos pradžioje) ir 67,8-79,0 \% (nupurškus 3 kartus). Purškiant 2 kartus ir 3 kartus skirtumai buvo statistiškai patikimi, palyginti su nepurkštais drègnuoju vandens garu laukeliais.

Antros apskaitos metu rudmargè cukrinius runkelius labiau buvo pažeidusi 2008 m. Purškimas drègnuoju vandens garu 2 kartus per runkelių vegetaciją neturèjo statistiškai patikimos įtakos rudmargès intensyvumui rugsèjo pabaigoje. Nupurškus 3 kartus patikimai sumažèjo rudmargès intensyvumas.

Baltulių intensyvumas cukrinių runkelių pasėlyje tyrimų metais buvo panašus ir pirmos, ir antros apskaitų metu. Rugpjūčio pradžioje nupurškus drègnuoju vandens garu baltulių intensyvumas sumažèjo 11,3-33,9 \% (priklausė nuo purškimų skaičiaus ir tyrimų metų), tačiau skirtumai nebuvo statistiškai patikimi. 2008-2009 m. rugsèjo pabaigoje drègnuoju vandens garu purkštuose laukeliuose baltuliu intensyvumas buvo patikimai mažesnis.

Miltligė tiriamuose laukeliuose išplito vẻlai. Pirmos apskaitos metu buvo aptikti tik nedideli pažeidimai. Antros 
2 lentelè. Grybinių ligų intensyvumas cukrinių runkelių pasèlyje \%

Table 2. Severity of sugar-beet fungal diseases, $\%$

\begin{tabular}{|c|c|c|c|c|}
\hline \multirow{2}{*}{ Variantas/Variant } & \multicolumn{2}{|c|}{ I apskaita / Count I (08 10) } & \multicolumn{2}{|c|}{ II apskaita / Count II (09 23) } \\
\hline & 2008 & 2009 & 2008 & 2009 \\
\hline & \multicolumn{4}{|c|}{ Rudmargè / Cercospora leaf spot } \\
\hline $\begin{array}{l}\text { 1. Purkšta herbicidais } \\
\text { Sprayed with herbicides }\end{array}$ & 1,57 & 1,18 & 8,80 & 3,50 \\
\hline $\begin{array}{l}\text { 2. } 2 \text { kartus purkšta vandens garais } \\
\text { Sprayed with damp water steam } \times 2\end{array}$ & 1,08 & 0,44 & 11,21 & 2,97 \\
\hline $\begin{array}{l}\text { 3. } 3 \text { kartus purkšta vandens garais } \\
\text { Sprayed with damp water steam } \times 3\end{array}$ & 0,33 & 0,38 & 4,07 & 1,70 \\
\hline \multirow[t]{2}{*}{$\mathrm{R}_{05} / L S D_{05}$} & 0,425 & 0,348 & 1,467 & 1,312 \\
\hline & \multicolumn{4}{|c|}{ Baltuliai / Ramularia leaf spot } \\
\hline $\begin{array}{l}\text { 1. Purkšta herbicidais } \\
\text { Sprayed with herbicides }\end{array}$ & 1,77 & 1,42 & 3,34 & 2,08 \\
\hline $\begin{array}{l}\text { 2. } 2 \text { kartus purkšta vandens garais } \\
\text { Sprayed with damp water steam } \times 2\end{array}$ & 1,36 & 1,68 & 2,19 & 0,98 \\
\hline $\begin{array}{l}\text { 3. } 3 \text { kartus purkšta vandens garais } \\
\text { Sprayed with damp water steam } \times 3\end{array}$ & 1,17 & 1,26 & 0,97 & 1,13 \\
\hline \multirow{2}{*}{$\mathrm{R}_{05} / L S D_{05}$} & 0,781 & 0,822 & 0,629 & 0,364 \\
\hline & \multicolumn{4}{|c|}{ Miltligè / Powdery mildew } \\
\hline $\begin{array}{l}\text { 1. Purkšta herbicidais } \\
\text { Sprayed with herbicides }\end{array}$ & 0,15 & 0,08 & 2,77 & 2,20 \\
\hline $\begin{array}{l}\text { 2. } 2 \text { kartus purkšta vandens garais } \\
\text { Sprayed with damp water steam } \times 2\end{array}$ & 0 & 0 & 1,03 & 1,16 \\
\hline $\begin{array}{l}\text { 3. } 3 \text { kartus purkšta vandens garais } \\
\text { Sprayed with damp water steam } \times 3\end{array}$ & 0 & 0,01 & 0,57 & 0,26 \\
\hline $\mathrm{R}_{05} / L S D_{05}$ & 0,016 & 0,031 & 0,615 & 0,518 \\
\hline
\end{tabular}

apskaitos metu miltligès intensyvumas drègnuoju vandens garu nepurkštuose laukeliuose buvo 2,20-2,77 \%. Dèl purškimo drègnuoju vandens garu patikimai sumažèjo miltligès intensyvumas - 47,3-88,2 \% (priklausè nuo tyrimų metų ir purškimų skaičiaus).

2008 m., vykdant bandymą, vizualiai pastebètas drègnojo vandens garo poveikis amarams, tačiau apskaitų neatlikta (pav.).

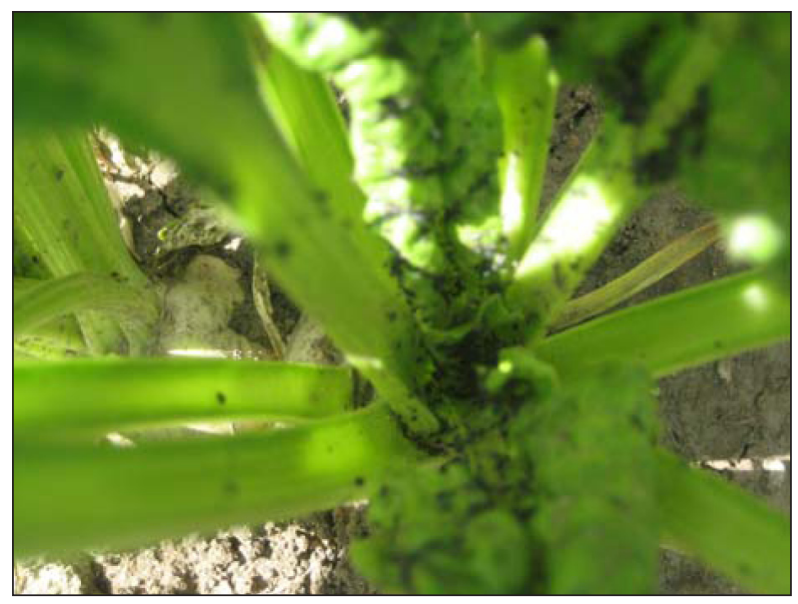

$A$
Drègnojo vandens garo poveikis amarams nustatytas ir ivertintas tik $2009 \mathrm{~m}$. laukeliuose, kuriuose liepos pradžioje panaudotas drégnasis vandens garas (3 variantas), amaru apniktų augalų kiekis sumažèjo 60,5 \%, o amarų ant augalo skaičius - 80,0 \% (3 lentelè).

Drėgnuoju vandens garu naikinant piktžoles, dirvos paviršiaus ir augalo aplinkos temperatūra trumpam laikui pakyla iki temperatūros, artimos garo temperatūrai. Šitaip

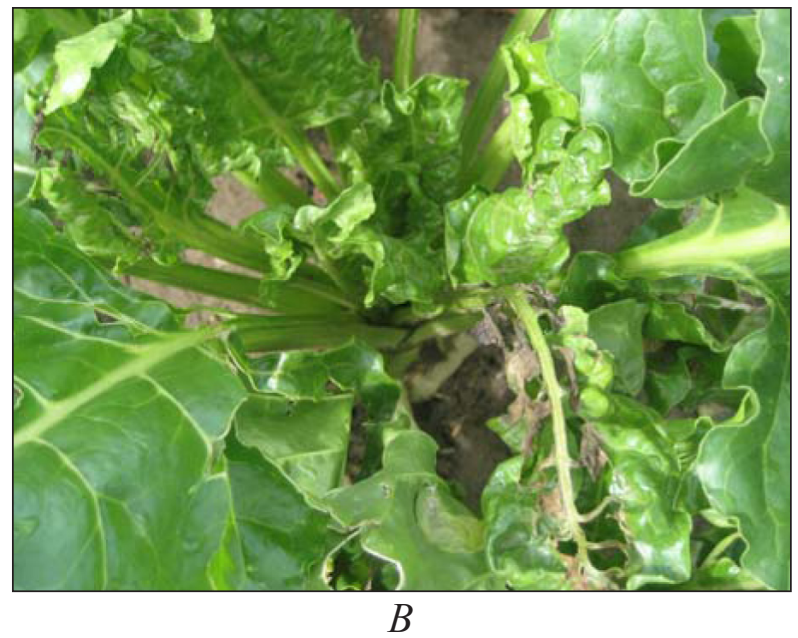

Pav. Cukrinis runkelis, apniktas pupinio amaro, prieš purškimą $(A)$, tas pats runkelis po purškimo $(B)$ drègnuoju vandens garu Figure. Sugar-beet with Aphis fabae before spraying (A), the same plant after spraing with damp water steam (B) 
3 lentelè. Pupinio amaro paplitimas cukrinių runkelių pasèlyje

Table 3. Distribution of Aphis fabae on sugar-beet

\begin{tabular}{|c|c|c|c|c|}
\hline \multirow[t]{2}{*}{ Variantas/Variant } & \multicolumn{2}{|c|}{$\begin{array}{l}\text { Amarų apniktų augalų skaičius \% } \\
\text { The number of plants with Aphis, \% }\end{array}$} & \multicolumn{2}{|c|}{$\begin{array}{l}\text { Amary ant augalo skaičius vnt. } \\
\text { The number of aphides per plant }\end{array}$} \\
\hline & I apskaita / Count I & II apskaita / Count II & I apskaita/Count I & II apskaita / Count /I \\
\hline $\begin{array}{l}\text { 1. Purkšta herbicidais } \\
\text { Sprayed with herbicides }\end{array}$ & 97,5 & 95,0 & 11 & 10 \\
\hline $\begin{array}{l}\text { 2. } 2 \text { kartus purkšta drègnuoju vandens garu } \\
\text { Sprayed with damp water steam } \times 2\end{array}$ & 95,0 & 97,5 & 8 & 12 \\
\hline $\begin{array}{l}\text { 3. } 3 \text { kartus purkšta drègnuoju vandens garu } \\
\text { Sprayed with damp water steam } \times 3\end{array}$ & 97,5 & 37,5 & 11 & 2 \\
\hline $\mathrm{R}_{05} / L S D_{05}$ & 15,77 & 18,90 & 3,86 & 4,614 \\
\hline
\end{tabular}

pakilusi temperatūra galëjo paveikti grybinių ligų sukėlëjus bei kenkèjus, todèl sumažèjo ligų pažeidimų intensyvumas bei amarų kiekis cukrinių runkelių pasèlyje. Tuo tarpu augalų audiniuose temperatūra nespèja pakilti daugiau kaip $58{ }^{\circ} \mathrm{C}$ (ši temperatūra sukelia baltymų koaguliaciją augalo ląstelèse ir augalas žūsta (Stašauskaitè, 1995)), todèl augalai išlieka nepažeisti.

\section{IŠVADOS}

1. Drègnasis vandens garas sumažino grybinių ligų vystymąsi cukrinių runkelių pasėlyje. Cukrinių runkelių pasėlius nupurškus drègnuoju vandens garu 3 kartus rudmargès intensyvumas rugsèjo pabaigoje buvo $51,4-59,8 \%$, baltulių - 45,7-70,9 \% mažesnis negu nepurkštuose laukeliuose.

2. Drègnuoju vandens garu nupurškus runkelius 3 kartus per vegetaciją ypač efektyviai $(79,4-88,2$ \%) sumažèjo miltligès intensyvumas.

3. Runkelius, apniktus amarų, nupurškus drègnuoju vandens garu, pažeistų augalų kiekis sumažèjo 60,5 \%, amarų ant augalo skaičius $-80,0 \%$.

Gauta 20110426 Priimta 20110816

\section{Literatūra}

1. Ascard J. 1995. Termal Weed control by Flaming. Dissertation Swedish University of Agricultural Sciences, Department of Agricultural Engineering. Report 200. Alnarp. P. 1-37.

2. Boten G. N., Šikalčik N. V. 2001. Reks - effektivnyi fungicid $\mathrm{v}$ borbie s cerkosporozom sacharnoi svyokly. Zashchita rastenii na rubezhe XXI veka: materialy nauchno-prakticheskoi konferencii. P. 166-168.

3. Collins R. M., Bertram A., Roche J.-A. et al. 2003. Preliminary studies in the comparison of hot water and hot foam for weed control. 5th EWRS Workshop on Physical and Cultural Weed Control Pisa. European Weed Research Society. P. 207-215.

4. Dabkevičius Z., Brazauskienè I. 2007. Augaly patologija. Akademija, Kèdainiu r.: Lietuvos žemdirbystės institutas. $493 \mathrm{p}$.
5. Gaurilčikienè I., Deveikytè I., Petraitienè E. 2006. Epidemic progress of Cercospora beticola Sacc. in Beta vulgaris L. under different conditions and cultivar resistance. Biologija. Vol. 4. P. 54-59.

6. Hanson D., Ascard J. 2002. Influence of developmental stage and time of assessment on hot water weed control. Weed Research. Vol. 42. P. 307-316.

7. Hudec K., Rohačik T. 2002. Alternaria alternata (Fr.) Keissler - new pathogen on sugar beet leaf in Slovakia. Plant Protection Science. Vol. 38(2). P. 81-82.

8. Kerpauskas P., Sirvydas A. P., Lazauskas P. et al. 2006. Possibilities of weed control by water steam. Agronomy Research. Vol. 4. P. 221-255.

9. Kurfess W. 2000. Untersuchungen zum Einsatz von Heißwasser zur thermishen Unkrautregulierung. Stuttgart. P. 126.

10. Limburg D. D., Mauk P. A., Godfrey L. D. 1997. Characteristics of beet yellows closterovirus transmission to sugar beeis by Aphis fabae. Phytopathology. Vol. 87(7). P. 766-771.

11. Meredith R. H., Morris D. B. 2003. Clothianidin on sugar beet: field Arial results from Northern Europe. Planzenschutz- Nachrichten Bayer. Vol. 56(1). P. 111-126.

12. Sirvydas A. P., Lazauskas P., Stepanas A. 2006. Plant temperature variation in the thermal weed control process. Zeitschrift für Pflanzenkrankheit und Pflanzenschutz. Sonderheft XX. P. 355-361.

13. Sirvydas A. P., Vasinauskienè R., Kerpauskas P. ir kt. 2008. Skrotelinių piktžolių terminès kontrolès ypatumai. Vagos: mokslo darbai. T. 79(32). P. 7-13.

14. Stašauskaitė S. 1995. Augalu vystymosi fiziologija. Vilnius: Aldorija. P. 50-78.

15. Tarakanovas P., Raudonius S. 2003. Agronominiu tyrimu duomeny statistine analize, taikant kompiuterines programas Anova, Stat, Split-Plot iš paketo Selekcija ir Irristat. Akademija: Lietuvos žemdirbystès institutas. P. 57.

16. Tei F., Stagnari F., Granier A. 2003. Preliminary results on physical weed control in spinach. European Weed Research Society. 5th EWRS Workshop on Physical and Cultural Weed Control Pisa. P. 164-171.

17. Virbickaite R., Sirvydas A. P., Kerpauskas P. 2006. The comparison of thermal and mechanical ways of weed control. Agronomy Research. Vol. 4 (Special issue). P. 451-455. 
18. Vizgirda M. 1997. Cukrinių runkelių sèklų apvèlimo insekticidais efektyvumas. Zemdirbyste- Agriculture: mokslo darbai. T. 57. P. 189-194.

19. Wolf P. F. J., Verreet J. 2002. The IPM sugar beet models. Plant Disease. Vol. 86(4). P. 336-344.

20. Žemès ükio augalu kenkèjai, ligos ir ju apskaita. 2002. J. Šurkus, I. Gaurilčikienė (sud.). Akademija, Kėdainių r.: Lietuvos žemdirbystès institutas. 345 p.

\section{Zita Brazienè, Regina Vasinauskienė}

\section{THE INFLUENCE OF DAMP WATER STEAM ON THE INCIDENCE OF FUNGAL DISEASES AND APHIDES IN SUGAR-BEET CROP}

Summary

Nowadays, with organic farming becoming more and more popular, the eco-friendly ways of pest destruction become very important. The focal attention is given to the control of weeds, because they are most harmful to agricultural crops. Also, crops are considerably damaged by widespread plant diseases and pests.

Field experiments of a destruction of weeds by creating a hightemperature medium (using a damp water steam) were carried out at the Experimental Station of the Aleksandras Stulginskis University in 2008-2009. In these studies, the effects of damp water steam on the incidence of fungal foliar diseases and aphids Aphis fabae Scop in sugar-beet crop was estimated.

The triplicate application of damp water steam during the sugarbeet growing season decreased fungal foliar disease severity. In the beginning of August (at the first accounting), the severity of fungal foliar diseases was by $48.1-55.6 \%$ lower as compared with control plots. During the second accounting at the end of September, the severity of fungal diseases in the plots affected by damp water steam was reduced by 54.2 to $58.3 \%$ as compared with control plots. At the first account, the severity of Cercospora beticola decreased substantially (by 73.2-80.2\%). At the second account, the greatest severity of desease was noted for Erysiphe betae (73.8-84.0\%).

The effect of damp water steam on aphids was established and estimated only in 2009. In the plots treated with damp water steam in the middle of July, the amount of plants with aphids decreased by $61.5 \%$, and the number of aphids on the plants decreased by $51.8 \%$ as compared with control (untreated) plots.

Key words: Aphis fabae, Ramularia beticola, Cercospora beticola, Erysiphe betae 